\title{
GUA WURU: FUNGSI DAN JENIS PEMANFAATANNYA DI KAWASAN PRASEJARAH GUNUNG SEWU BAGIAN BARAT
}

\section{WURU CAVE: ITS FUNCTION AND TYPE OF UTILIZATION IN THE GUNUNGSEWU PREHISTORIC AREA}

\author{
Alifah \\ ali.alifah@gmail.com
}

\begin{abstract}
Wuru cave which located in Jetis, Saptosari Gunung Kidul, is one of the horizontal caves that contain archaeological data. This cave have a relatively small room, elongated and curved, but in this cave has many ecofact, some of which indicate the presence of human treatments (burned and trimmed). In the quality of the bone ecofact most have begun to experience the process of fossilization. In addition there is also finded shells, pottery, hazelnut and coal. These findings show evidence that the Wuru cave has potential as a cave who ever used in the past. But what kind of use or functionality of this cave in the surrounding area of Gunung Sewu western part is still unknown. This paper seeks to uncover the environmental approach, the method used is the analysis of artifacts, ecofact, and ecology around the area of the cave.
\end{abstract}

Keywords: Wuru Cave, Function Cave, Environmental approach.

\begin{abstract}
ABSTRAK
Gua Wuru yang terletak di Desa Jetis, Kecamatan Saptosari Gunung Kidul, merupakan salah satu gua horisontal yang memiliki kandungan data arkeologi. Gua ini secara morfologi, memiliki ukuran yang relatif kecil dengan ruangan yang memanjang dan berkelok, namun hasil survey yang dilakukan Balai Arkeologi pada tahun 2013 di gua ini ditemukan banyak ekofak yang beberapa di antaranya mengindikasikan adanya perlakuan manusia (dibakar dan dipangkas). Secara kualitas ekofak tulang tersebut sebagian telah mulai proses fosilisasi. Selain ekofak tulang terdapat pula temuan cangkang kerang, fragmen gerabah, kulit kemiri dan arang. Temuan ini menunjukan bukti bahwa Gua Wuru memiliki potensi sebagai gua yang pernah dimanfaatkan manusia pada masa lalu. Berdasarkan temuan survey tersebut, belum dapat diketahui fungsi dan jenis pemanfaatan Gua Wuru yang ada di kawasan Gunung Sewu bagian Barat. Tulisan ini berupaya untuk mengungkapnya dengan menggunakan pendekatan lingkungan, metode yang digunakan adalah analisis artefak, ekofak dan ekologi sekitar kawasan gua.
\end{abstract}

Kata kunci: Gua Wuru, Fungsi Gua, Pendekatan lingkungan.

Tanggal masuk : 25 Februari 2015

Tanggal diterima : 28 April 2015 


\section{PENDAHULUAN}

Kajian tentang pemukiman atau hunian merupakan salah satu kunci untuk mengetahui relasi antara manusia dan ruang (Ahimsa-Putra, 1995). Hunian yang paling sederhana telah muncul pada masa prasejarah. Hunian pada masa ini sangat bergantung pada faktor lingkungan, karena cenderung melakukan strategi subsistensinya pada tempat-tempat yang dekat dengan air, sumber makanan dan tempat yang dianggap aman dan nyaman (Said dan Utomo, 2006). Berbicara mengenai hunian prasejarah, tidak lepas dari keberadaan gua sebagai awal manusia bertempat tinggal. Gua sebagai hasil bentukan alam mulai dimanfaatkan oleh manusia untuk pertama kali sebagai lahan hunian pada kala plestosen akhir hingga awal holosen. Pada tingkat budaya ini telah terjadi model budaya hidup dari berpindah ke arah budaya yang lebih menetap (Simanjuntak, 2000). Namun tidak semua gua dapat dihuni oleh manusia, sebab ada beberapa kriteria mengenai layak tidaknya gua itu dijadikan tempat tinggal, antara lain memiliki ruang yang cukup luas, cukup sinar matahari, sirkulasi udara baik, tidak lembab, serta dekat dengan sumberdaya alam pendukungnya, yaitu air dan sumber makanan baik tumbuhan maupun binatang (Butzer, 1964 dalam Said, 2006).

Kawasan Gunung Sewu sebagai bagian dari Pegunungan Selatan Jawa adalah kawasan yang sangat kaya akan tinggalan arkeologis, sehingga layak untuk disebut sebagai kawasan arkeologis (Yuwono, 2004). Kawasan yang bercirikan ribuan bukit karst yang menampilkan sejarah kehidupan manusia, setidaknya sejak kala Pleistosen Akhir hingga Holosen Awal merupakan Wilayah perbukitan karst yang terpenting dalam prasejarah Nusantara karena kekayaan situs dan tinggalan yang dikandungnya. Salah satu karakter budaya yang khas di kawasan ini adalah pemanfataan gua dan ceruk secara intensif (Simanjuntak,1999).

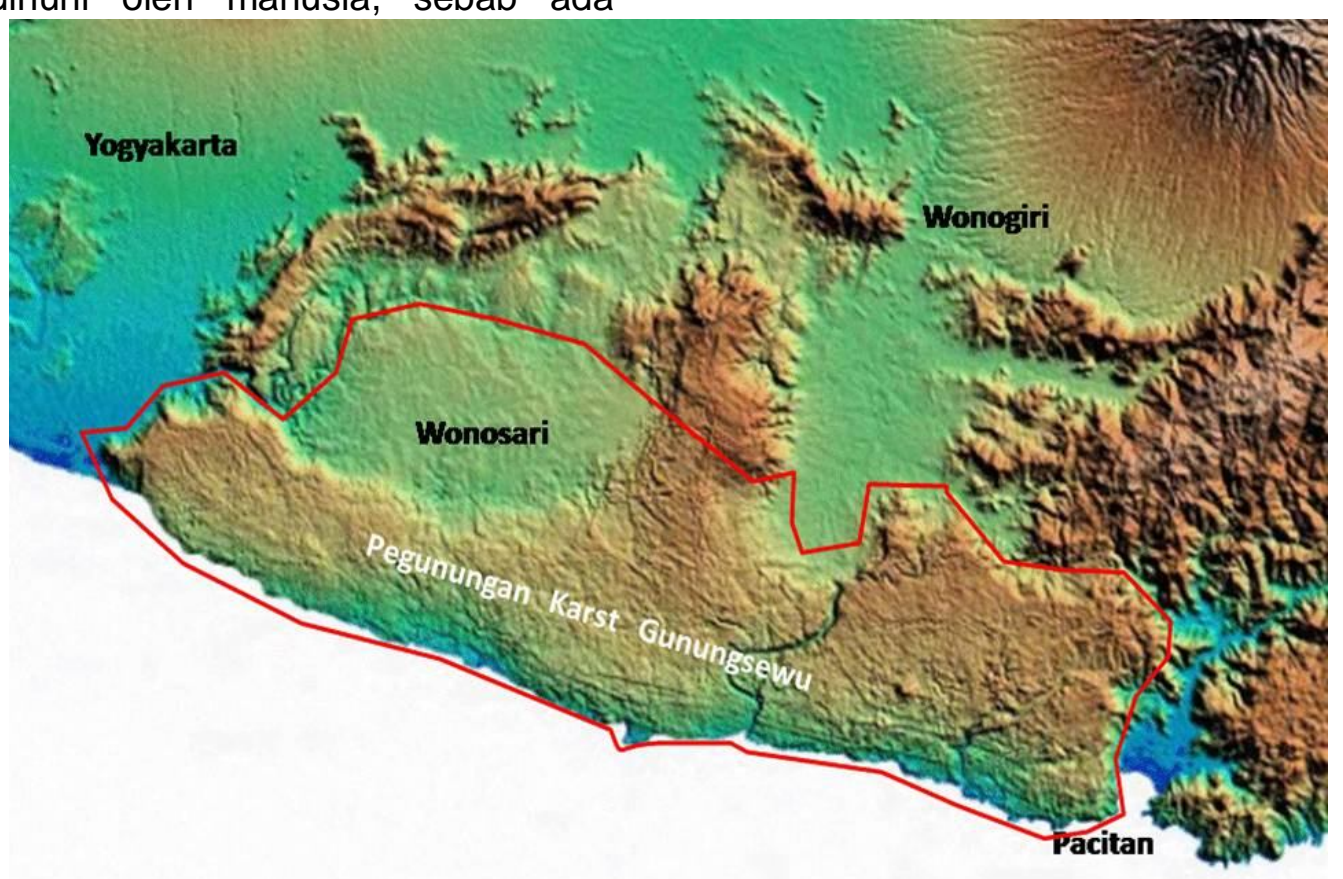

Gambar 1. Peta Kawasan Gunung Sewu. Sumber: http://blog.fitb.itb.ac.id diunduh pada 30 Desember 2014 
Beberapa penelitian arkeologi yang telah dilakukan menunjukan data yang signifikan atas situs-situs hunian gua yang ada dikawasan ini. Situs-situs gua memiliki bentuk pemanfaatan lahan serta jenis artefak dan ekofak yang khas. Gua selain digunakan sebagai hunian, juga dimanfaatkan sebagai ruang kerja (pembuatan peralatan seperti alat batu dan alat tulang), juga difungsikan sebagai kubur (Nurani, 2006). Gua di Kawasan Gunung Sewu digunakan sebagai lokasi hunian dan berbagai aktivitas lain setidaknya berlangsung sejak 60.000 (Gua Tabuhan) hingga 800 BP (Song Keplek) BP (Simanjuntak, 2000). Budaya yang berkembang pada masyarakat penghuni gua ini adalah budaya mesolitik yang dicirikan dengan artefak batu berupa alat-alat serpih, perkutor dan batu inti (Simanjuntak, 2000). Namun demikian hunian gua masih berlangsung dan berkembang pada masa neolitik. Perbedaan perkembangan budaya cukup terlihat pada masa neolitik yaitu dengan dikenalnya teknologi pengupaman sehingga dihasilkan berbagai alat litik dan tulang yang memiliki kualitas yang jauh lebih baik dari masa sebelumnya. Selain itu pada masa ini juga telah dikenal teknologi pembuatan gerabah (Simanjuntak, 2000).

Penelitian yang dilakukan

oleh Balai Arkeologi Yogyakarta pada tahun 2013, di Kecamatan Saptosari Gunung Kidul menemukan sebuah gua yang memiliki temuan ekofak dan artefak dalam kondisi yang fragmentaris yaitu di Gua Wuru (Tim, 2013). Temuan ini berada pada tanah hasil galian penambang guoano yang tersebar dilantai mulut gua dan beberapa di bagian lantai dalam gua. Temuan ini cukup menarik mengingat jumlah dan jenis temuan yang mengindikasikan adanya aktifitas manusia masa lampau (Alifah, 2013).Secara morfologi, Gua Wuru memiliki kondisi ruangan yang sempit memanjang dan berkelok (lebar $3 \mathrm{~m}$, panjang 15 meter dan tinggi 7 meter) serta kondisi pencahayaan yang tidak terlalu baik.Beberapa sampel temuan yang dibawa menunjukan jenis ekofak yang berbeda-beda serta beberapa diantaranya menunjukan adanya indikasi pemangkasan pada bagian tulang. Keberadaan temuan ini memunculkan pertanyaan: apa Fungsi dan jenis pemanfaatan Gua Wuru yang berada di kawasan Gunung Sewu Bagian Barat? Permasalahan ini menarik untuk diungkap mengingat kondisi morfologi serta temuan yang dikandungnya. Selain potensi yang dimiliki oleh Gua Wuru juga keletakannya yang berada di antara gua-gua yang dinilai memiliki potensi sebagai hunian manusia masa prasejarah.

\section{KERANGKA TEORI}

Berangkat dari permasalahan yang diangkat, dalam menjelaskan fungsi dan jenis pemanfaatan Gua Wuru akan digunakan pendekatan lingkungan. Karena dalam beberapa hal, lokasi situs juga mereflesksikan tipe-tipe situs. Lokasi tempat keberadaannya dapat merefleksikan lingkungan dan teknologinya. (Judge, 1971). Pendekatan lingkungan ini menekankan pada hubungan antara variable manusia dengan variable lingkungan. Pendekatan ini diterapkan untuk memberikan informasi tentang unsur biofisik, biokultur maupun kondisi fisiografi in situ (Bintarto, 1995). Situs arkeologi merupakan gambaran tentang aktivitas manusia masa lalu dengan lingkungannya. Untuk melakukan aktivitasnya, 
manusia memilih lokasi-lokasi yang yang disesuaikan dengan strategi subsistensinya (Subroto, 1995).

Manusia penghuni gua memiliki strategi subsistensi berburu dan meramu (Simanjuntak, 2000). Makanan sebagai kebutuhan dasar diperoleh dengan caramemetik dari alam. Masyarakat pemburu dan peramu pada umumnya cenderung hidup secara nomaden, namun demikian mereka membuat came site (hunian tetap) di sekitar sumber air (Yuwono, 1995). Gua-gua yang berada di sekitar sumber air inilah yang memiliki kemungkinan besar dimanfaatkan sebagai came site, dan kemudian berkembang menjadi hunian tetap pada masa berikutnya. Pada masa ini manusia masih sangat tergantung pada kondisi sumberdaya yang dimiliki oleh alam lingkungan sekitarnya. Sementara kondisi lingkungan merupakan sesuatu yang dinamis, sehingga tempat bermukim dapat dikatakan sebagai suatu strategi adaptasi manusia terhadap lingkungan sesuai dengan teknologi dan sistem sosial yang telah dicapai. Menurut Mundarjito, 1995, menyatakan bahwa untuk memahami hal tersebut, ada tiga hal yang perlu diperhatikan yaitu: persebaran, hubungan, dan satuan ruang serta asumsi-asumsi dasar yang melatarbelakanginya. Dalam pengamatan selanjutnya luasan kawasan ruang yang ada perlu diketahui.

$$
\text { Untuk menghubungkan }
$$
antara lingkungan dengan teknologi dan subsistensi digunakan pandangan Steward, tentang ekologi budaya yang berupaya memahami bagaimana manusia sebagai mahluk hidup menyesuaikan dirinya dengan lingkungan geografi tertentu. Steward menyatakan bahwa kebudayaan terdiri dari inti (core) dan pinggiran (periphery). Teori Steward berpusat di sekitar inti budaya, yang didefinisikan sebagai "konstelasi fitur yang paling erat kaitannya dengan kegiatan subsisten dan pengaturan ekonomi" (Steward, 1955). Dalam pandangan Steward Inti kebudayaan adalah bagian yang bersentuhan langsung dengan adaptasi manusia dengan lingkungan yang menghasilkan tekno-lingkungan yang merupakan hasil dari kreativitas manusia (Hudayana, 2001).

\section{GUA WURU DAN KANDUNGAN DATA ARKEOLOGI}

\section{Morfologi dan Lingkungan Gua Wuru}

Gua Wuru terletak di Dusun Jetis, Desa Jetis Kecamatan Saptosari Gunung Kidul. Terletak pada Koordinat $08^{0} 01^{\prime}$ 53.8" Lintang Selatan dan 110 $29^{\prime}$ 47.7" Bujur Timur, dengan ketinggian $330 \mathrm{~m}$ dpl. Gua ini berada pada lereng bukit bagian tengah dengan kemiringan lereng sedang. Di depan Gua Wuru membentang lembah yang cukup lebar yang membujur dengan arah timur-barat.

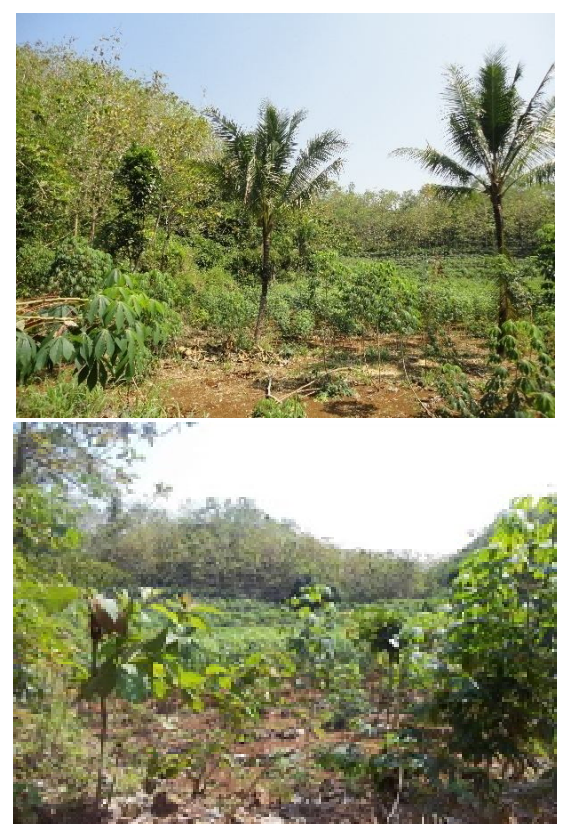

Gambar 2. Lembah subur di depan Gua Wuru. Dok: Balai Arkeologi Yogyakarta, 2013 
Saat ini disekitar Gua Wuru merupakan lahan hutan jati dan lembah didepan Gua Wuru merupakan ladang yang ditanami ketela.
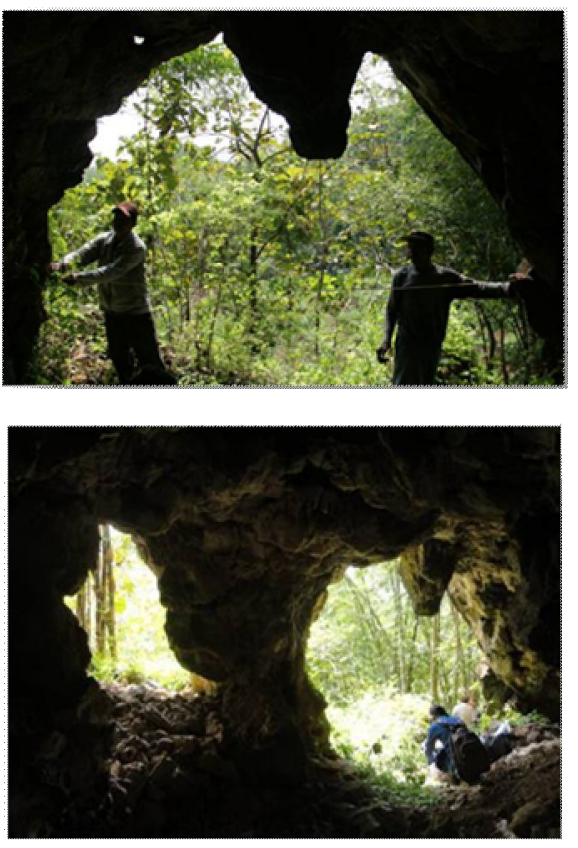

Gambar 3. Mulut Gua Wuru.

Dok: Balai Arkeologi Yogyakarta, 2013.
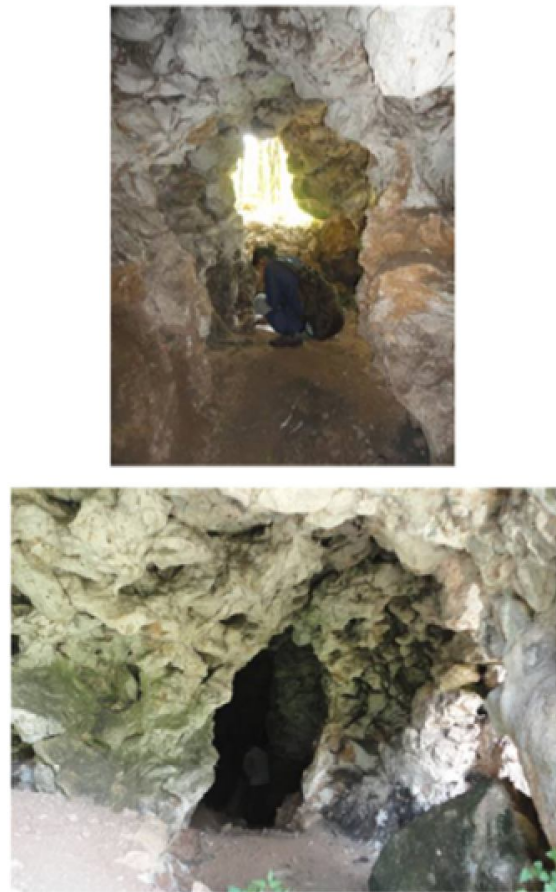

Gambar 4. Kondisi ruangan Gua Wuru. Dok: Asikin, 2013.
Kondisi gua saat ini merupakan lokasi penambangan tanah untuk bahan pupuk yang terbengkalai karena ditinggalkan oleh para penambang. Lapisan tanah yang sudah tergali kurang lebih setebal 2 meter dari permukaan tanah semula (diukur dari tanah yang ada di dinding gua). Kondisi ini menyebabkan tersingkapnya temuan arkeologi berupa ekofak dan artefak yang tersebar di tumpukan bekas galian serta beberapa diantaranya berada di lantai ruangan gua.

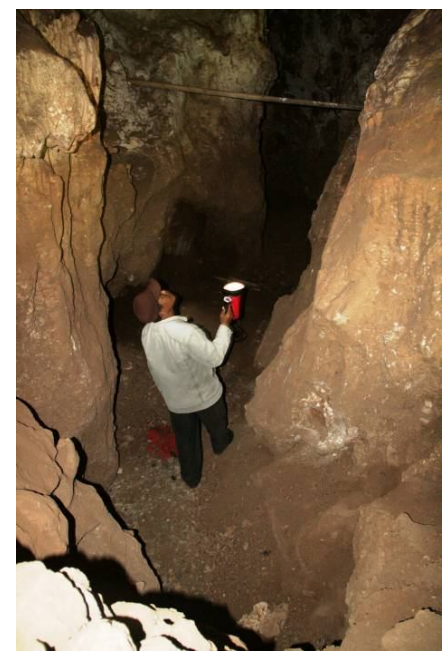

Gambar 5. Kondisi lantai ruangan gua yang telah ditambang. Dok: Balai Arkeologi Yogyakarta, 2013.

Secara geologis, Gua Wuru tersusun oleh jenis karst coral reef yang memiliki porositas tinggi karena memiliki banyak lubang pada dinding guanya. Kondisi ini membuat lapisan dinding gua mudah mengalami pelapukan yang kemudian terendapkan kebawah menyusun lapisan lantai gua.

Secara geomorfologis, Gua Wuru terletak pada daerah karst dengan tipe labirin. Tipe karst labirin merupakan tipe karst yang dicirikan dengan koridor-koridor lembah yang terkontrol oleh adanya sesar atau kekar. Morfologi karst tersusun atar balok balok gamping yang dipisahkan oleh lembah atau ngarai yang memanjang sebagai hasil 
proses terbentuk oleh proses pelarutan yang intensif pada jalur sesar atau kekar (Haryono, 2001).Lingkungan selitar Gua Wuru menyediakan banyak sumber air diantaranya Tlogo Ndondong, Tlogo Tritis, Tlogo Sumber, Tlogo Mandung dan aliran sungai periodic di sekirar radius 5 kilo meter.

\section{Ekofak Cangkang Kerang Dan Tulang}

Beberapa temuan arkeologis yang dibawa dari Gua Wuru setelah diidentifikasi diketahui jumlah dan keragaman temuan yang ada. ${ }^{1}$ Temuan-temuan tersebut berada dalam kondisi yang fragmentaris dengan ukuran panjang antara 1-10 $\mathrm{cm}$. kondisi ekofak yang fragmentaris ini diyakini bukan merupakan patahan baru, karena permukaan patahan tulang tidak menunjukan tanda-tanda fresh cut. Temuan ekofak yang telah diidentifikasi ini terdiri atas 5 buah cangkang kerang, 4 buah dentary (temuan gigi lepas) binatang, dan 51 fragmen tulang binatang. Berikut data selengkapnya:

Tabel 1. Temuan ekofak cangkang kerang dan tulang di Gua Wuru

\begin{tabular}{|l|l|l|l|l|}
\hline No & \multicolumn{1}{|c|}{ Organ } & Condividue & Jml & \multicolumn{1}{|c|}{ Keterangan } \\
\hline 1 & Cangkang kerang & 1 & Marine (kerang laut) \\
\hline 2 & Cangkang kerang & Mactridae & 3 & Marine (kerang laut) \\
\hline 3 & Cangkang kerang & Ampidromus & 1 & Land snail (siput darat) \\
\hline 4 & Scapula & Aves & 1 & \\
\hline 5 & Incisivus inverior & Sus & 1 & \\
\hline 6 & Costae & Sus & 2 & \\
\hline 7 & Dentary & Bos & 3 & \\
\hline 8 & Vertebre & Bos & 2 & \\
\hline 9 & Metatarsal & Bos & 1 & \\
\hline 10 & Epicondilus distal & Bos & 1 & Tulang terbakar \\
& metacarpal & & & \\
\hline 11 & Caput femuri & Bos & 1 & \\
\hline 12 & Prosecus spinosus & Bos & 2 & \\
\hline 13 & Longbone & Bos & 5 & \\
\hline 14 & Longbone & Bos & 1 & Ada indikasi dikerjakan \\
\hline 15 & Vertebre & Cervus & 1 & Tulang terbakar \\
\hline 16 & Femur & Cervus & 1 & Mulai mengalami proses fosilisasi \\
\hline 17 & Humerus & Cervus & 1 & \\
\hline 18 & Distal humerus & Cervus & 2 & \\
\hline 19 & Metatarsal & Cervus & 1 & \\
\hline 20 & Metacarpal & Cervus & 1 & Mulai mengalami proses fosilisasi \\
\hline 21 & Distal metatarsal & Cervus & 2 & \\
\hline 22 & Longbone & Cervus & 2 & Konkresi gamping \\
\hline 23 & Longbone & Cervus & 8 & Ada indikasi dikerjakan \\
\hline 24 & Longbone & Cervus & 10 & Terbakar \\
\hline 25 & Costae & Cervus & 2 & Terbakar \\
\hline 26 & Astragalus & Cervus & 1 & Mulai mengalami proses fosilisasi \\
\hline 27 & Phalanges $1^{\text {st }}$ & Cervus & 1 & \\
\hline 28 & Phalanges 3nd & Cervus & 2 & \\
\hline
\end{tabular}

1. Namun demikian temuan ini hanya sebagian saja secara acak yang merupakan sampel yang dianggap mewakili dari temuan yang ada dengan pertimbangan ukuran dan kondisi temuan 

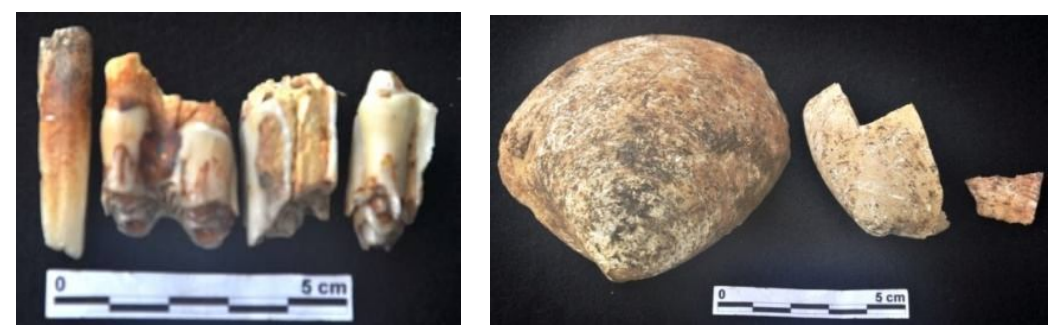

Gambar 6. Beberapa temuan gigi lepas binatang (dentary) dan cangkang kerang dari Gua Wuru. Dok: Alifah, 2014

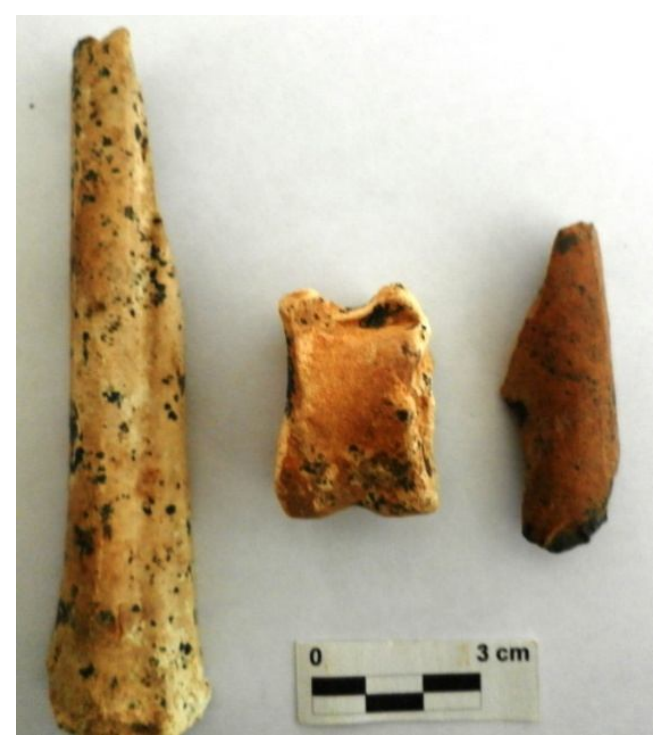

Gambar 7. Tiga sampel fragmen tulang yang telah mengalami proses fosilisasi. Dok: Alifah,2014.

\section{Kulit kemiri}

Di Gua Wuru juga ditemukan ekofak dari tumbuhan, yaitu kulit biji kemiri. Temuan ini bercampur dengan temuan ekofak tulang dan kerang serta arang kayu. Kemiri yang merupakan biji dari tanaman keras saat ini masih banyak ditemukan di sekitar Kawasan Gunung Sewu. Kondisi temuan biji kemiri sudah dalam keadaan pecah dan telah mengalami pengerasan akibat adanya proses karstifikasi.

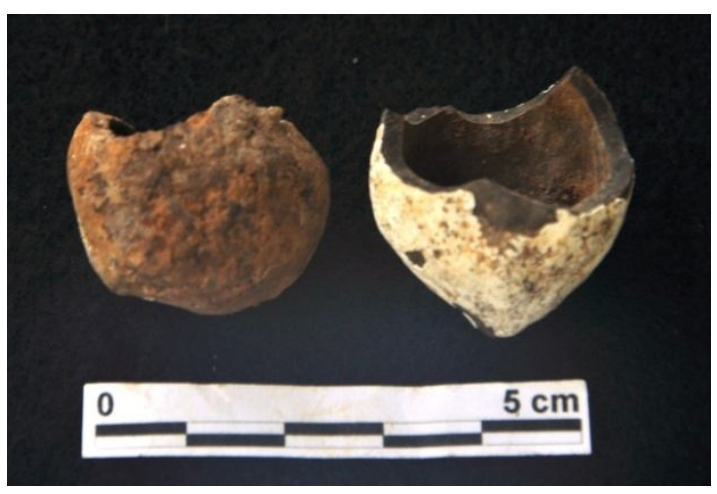

Gambar 8. Kulit biji kemiri dari Gua Wuru. Dok:Alifah, 2014. 


\section{Artefak Gerabah}

Artefak lain yang ditemukan di Gua Wuru berupa 12 fragmen gerabah. Berdasarkan identifikasi bentuk, diketahui bahwa 12 fragmen gerabah tersebut berasal dari bentuk wadah semacam periuk. Permukaan gerabah memiliki lapisan slip yang masih terlihat pada bagian permukaan fragmen gerabah. Berdasarkan pengamatan pada permukaan gerabah diketahui bahwa gerabah tersebut dibuat dengan teknik roda putar cepat yang dicirikan dengan adanya garis melingkar secara tipis pada bagian permukaan luar.

\section{Artefak Batu}

Artefak berbahan batu yang ditemukan di Gua Wuru hanya merupakan tatal batu berjumlah 3 buah. Tatal batu ini berbahan batu rijang (hasil pengamatan Ir. Hendy Soesilo).
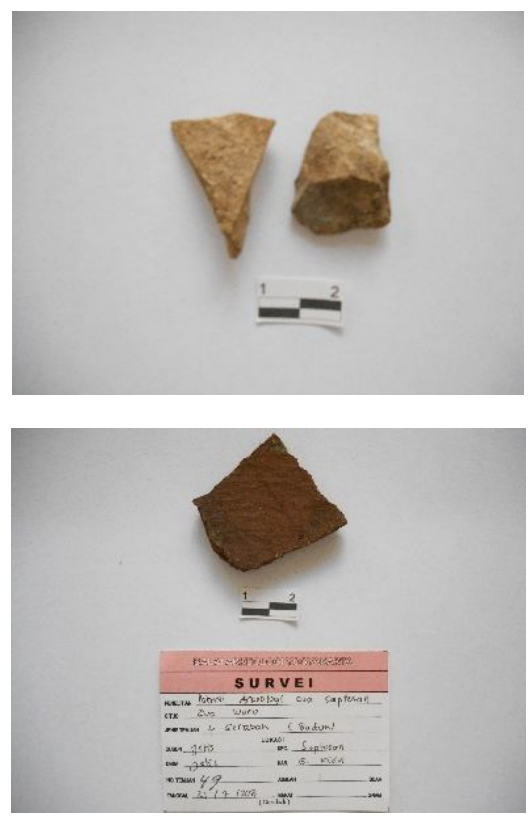

Gambar 9. Tatal batu (atas) dan gerabah (bawah) dari Gua Wuru. Dok: Alifah

\section{Gua-Gua disekitar Gua Wuru}

Berdasarkan hasil survei yang telah dilakukan oleh Balai Arkeologi Yogyakarta tahun 2013 serta Sofian 2007 (Tim, 2013 dan Sofian, 2007), diketahui terdapat gua-gua yang secara morfologi, lingkungan dan kandungan data dinilai memiliki potensi sebagai hunian manusia masa prasejarah. Gua-gua tersebut berada di sekitar Gua Wuru dalam radius 5 kilo meter ${ }^{2}$ yang berada di Kecamatan Saptosari dan Kecamatan Paliyan. Setidaknya terdapat 14 gua yang memiliki potensi arkeologi sebagai hunian. Namun, setelah dilakukan pembobotan maka diketahui bahwa gua yang memiliki potensi tinggi sebagai hunian manusia prasejarah adalah Gua Sodong, Gua Putat A, Gua Wura-Wari Gua Song Sodong Gua Tritis Ngloro, Gua Tlogo Randu 1 dan Gua Sumber. Gua-gua ini memiliki jarak kurang dari 5 kilometer dari Gua Wuru serta dari memiliki jarak yang relatif dekat dengan sumber-sumber air berupa telaga dan sungai periodik. Sumber air yang ada disekitar radius 5 kilo meter ini terdapat sumber air seperti Tlogo Ndondong, Tlogo Sumber, Tlogo Tritis, Tlogo Manggul dan aliran sungai musaman di sekitar gua Landak, dan beberapa sumber air lain.

2. Digunakan batasan 5 kilometer berdasarkan paradigm cakupan situs (Ahimsha-Putra, 1995). Dimana makin jauh jarak suatu sumberdaya dari situs maka sumberdaya tersebut menjadi kurang menarik. Jarak 5 kilometer dianggap sebagai jangkauan yang dapat ditempuh oleh manusia yang melakukan aktivitas di Gua Wuru dan sekitarnya. 


\section{Peta Lokasi Penelitian dan Sebaran Gua serta Sumber Subsistensinya}

옹 임

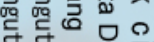
ఫ ఫ 도오을

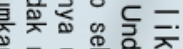
큰듀 흥

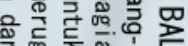
중조

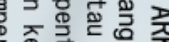

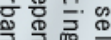

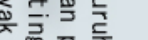
임 즞 突 旁市

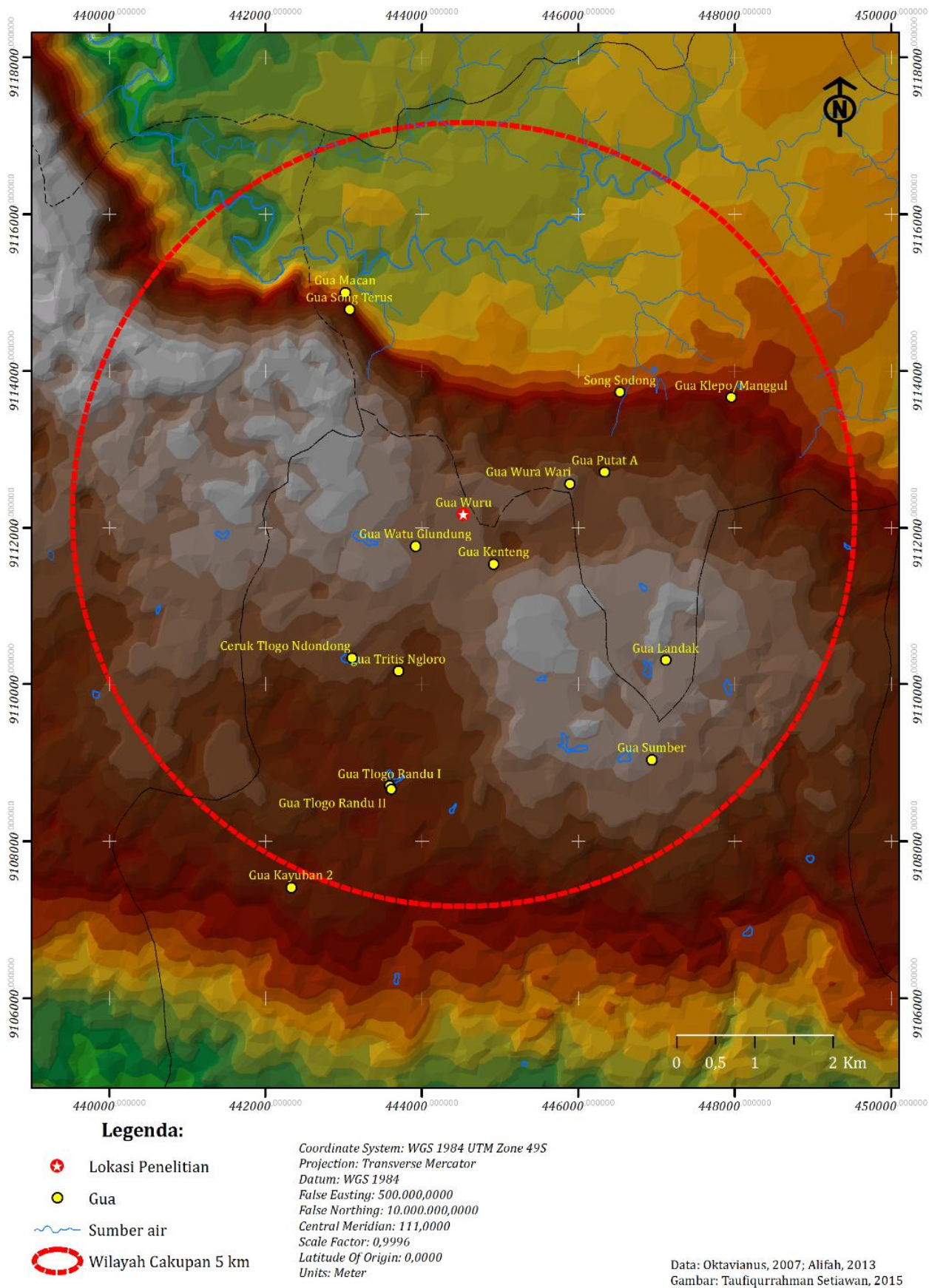

Gambar 10. Peta Gua-Gua di sekitar Gua Wuru. 
PEMBAHASAN

Berdasarkan hasil analisis ekofak diketahui bahwa temuan tulang binatang paling banyak berasal dari cervus (sejenis kijang kemungkinan, yaitu pertama gua tersebut digunakan sebagai tempat lindung binatang dan akhirnya mereka mati disitu, kedua gua tersebut merupakan tempat berlindung manusia, sehingga

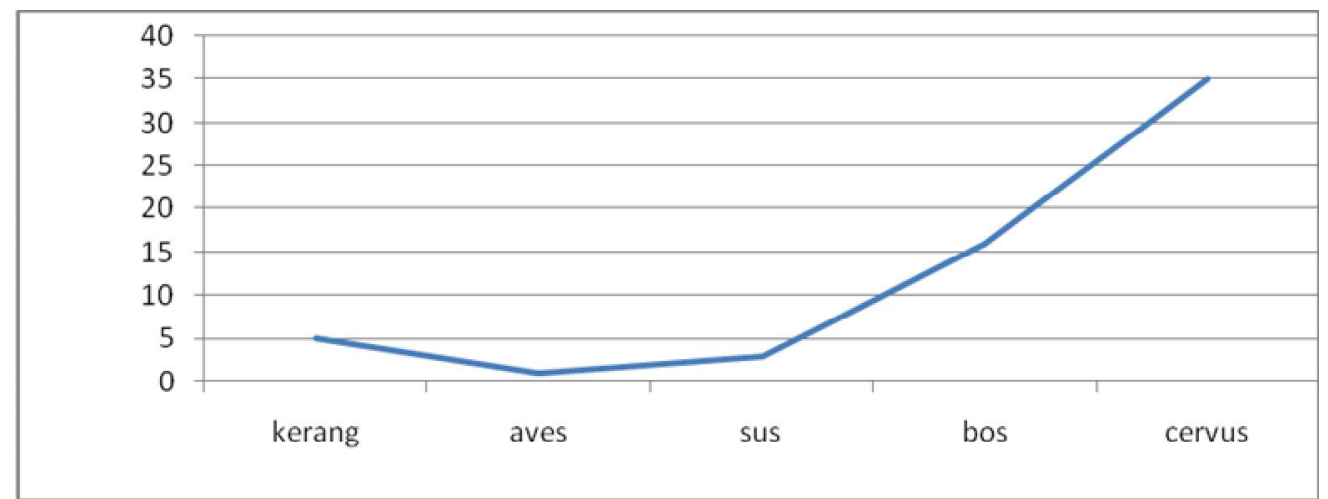

Gambar 11. Grafik temuan ekofak berdasarkan anatomi bagian tulang yang menunjukan bahwa bagian tulang panjang merupakan temuan yang paling dominan.

dan rusa), dilanjutkan dengan bos.Tulang dari binatang lain hanya ditemukan beberapa saja yaitu sus dan aves.

Berdasarkan hasil identifikasi temuan ekofak, secara anatomis bagian tulang yang banyak ditemukan adalah tulang panjang (longbone, humerus, metatarsal, metacarpal, femur).

\section{Ditemukannya akumulasi} tulang binatang memiliki dua meninggalkan sisa-sisa binatang yang mereka buru dan konsumsi (Siswanto, 2012).

Temuan akumulasi ekofak tulang di Gua Wuru ini rupaya mengindikasikan kemungkinan yang kedua. Indikasi ini diperkuat dengan ditemukannya fragmen tulang yang menunjukan tanda - tanda pemangkasan. Tanda-tanda pemangkasan ini dijumpai pada beberapa bagian tulang panjang.

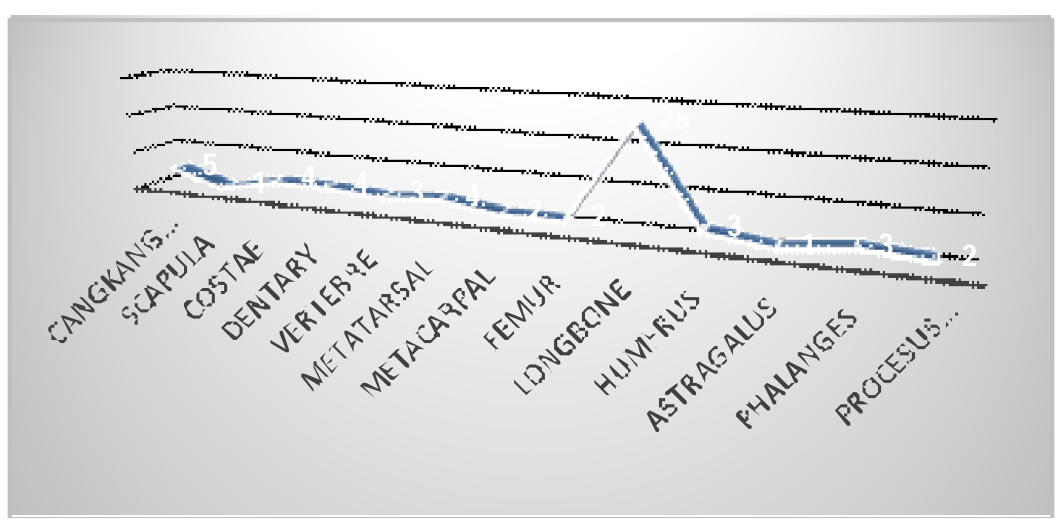

Gambar 12. Grafik temuan ekofak berdasarkan jenis binatang. 

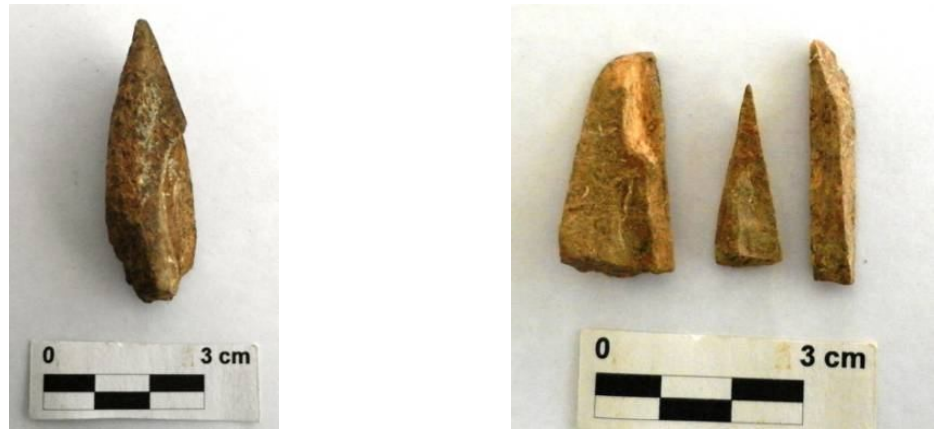

Gambar 13 Temuan fragmen tulang yang mengindikasikan adanya proses pemangkasan, yang berasal dari tulang panjang bos (kiri) dan Tulang panjang cervus (kanan). Dok: Alifah, 2014

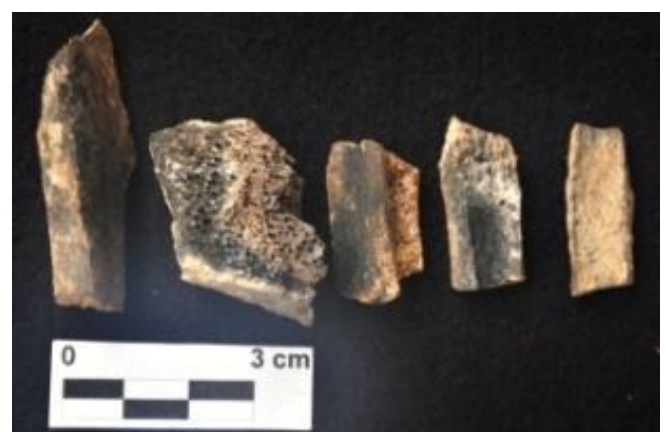

Gambar 14. Fragmen tulang terbakar. Dok: Alifah, 2014.

Selain tulang yang dipangkas, terdapat pula beberapa fragmen tulang yang menunjukan jejak terbakar dari jenis binatang bos dan cervus. Kedua temuan tersebutmemunculkan interpretasi adanya aktivitas manusia yang dilakukan terkait dengan pengunaan Gua Wuru sebagai tempat manusia beraktivitas. Temuan 4 buah cangkang kerang dari jenis conidae dan mactridae yang memiliki habitat di daerah pesisir dan laut dangkal (Dharma, 1992), juga mendukung interpretasi tersebut. Keberadaan cangkang kerang tersebut menunjukan adanya aktifitas manusia yang membawa hingga sampai pada lokasi gua yang ada di wilayah pedalaman (jauh dari pesisir). Kehadiran artefak tatal batu dan fragmen gerabah semakin memperkuat interpretasi bahwa himpunan ekofak yang ada di Gua Wuru ini merupakan hasil dari aktivitas manusia masa lalu.
Secara kualitatif, beberapa temuan tulang menunjukan adanya indikasi proses fosilisasi. Indikasi proses fosilisasi ditemukan pada ekofak dari cervus. Secara teori waktu yang dibutuhkan untuk proses fosilisasi adalah minimal 7.000 tahun (Widianto, 2006). Sehingga temuan ini dapat digunakan untuk mengetahui umur relatif dari pemanfaatan Gua Wuru yaitu sekitar 7.000 tahun yang lalu.Pada masa ini hunian gua sangat popular di kawasan Gunung Sewu, yang menghasilkan budaya mesolitik yang memiliki ciri khas adanya eksploitasi intensif terhadap suberdaya lingkungan, meliputi fauna, batuan, gua dan ceruk.

Dari hasil identifikasi terhadap masing - masing temuan diketahui bahwa prosentase ekofak jauh lebih besar dari artefak yang ada. Temuan yang ada di Gua Wuru didominasi oleh ekofak tulang. Menurut penelitian etnografis yang dilakukan oleh Shott (1986 dalam Prasodjo, 2002) terhadap beberapa masyarakat berburu dan mengumpulkan makanan melihat adanya hubungan antara pergerakan atau mobilitas dengan jumlah dan keragaman temuan alat atau artefak. Hubungan tersebut adalah bahwa semakin tinggi variabilitas alat yang dimiliki maka semakin kecil mobilitas perpindahan masyarakat tersebut. Seperti tergambar dalam grafik 


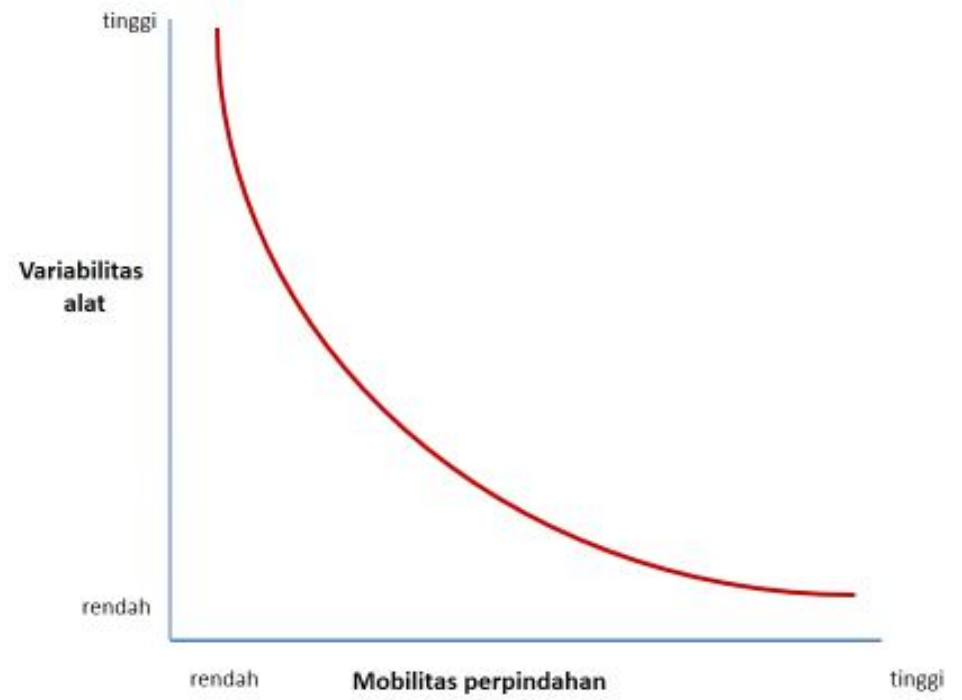

Gambar 15. Grafik Shott tentang hubungan antara variabilitas dan mobilitas. Sumber Prasodjo.

Berdasarkan grafik diatas maka dianalogikan bahwa manusia yang memanfaatkan Gua Wuru bersifat sementara yaitu sebagai transit site. Berdasarkan fungsi dan jenis aktivitasnya, situs hunian arkeologi dapat dibedakan menjadi situs habitasi, situs penjagalan/perburuan, situs penambanagn, situs perdagangan, situs seremonial, dan situs perbengkelan (Hole and Heria, 1973). Pengamatan terhadap potensi lingkungan di sekitar Gua Wuru menunjukan bahwa situs ini sebagai transit site untuk keperluan perburuan. Penempatan Gua sebagai tempat aktivitas dimungkinkan berkaitan dengan musim, dimana pada musim tertentu terdapat banyak binatang yang dapat diburu dan diolah di sekitar Gua Wuru. Interpretasi ini didasari pada jumlah temuan ekofak tulang yang didominasi oleh fragmen tulang panjang ${ }^{3}$. Berdasarkan keletakan Gua yang berada pada lembah

${ }^{3}$ Bagian tulang panjang merupakan bagian yang paling banyak mengandung daging sebagai pemenuhan kebutuhan makanan. antara dua puncak perbukitan sangat memungkinkan lokasi ini menjadi menjadi tempat berkumpulnya binatang.

$$
\text { Seperti telah disinggung }
$$

diatas, pemanfaatan gua di Gunung Sewu menunjukan pola tersendiri. Gua di kawasan ini selain digunakan sebagai hunian juga digunakan untuk berbagai aktifitas lain seperti penguburan, perbengkelan, dan pengolahan makanan (Nurani, 2006). Lain halnya dengan pemanfaatan gua-gua yang ada di kawasan Jawa bagian Timur seperti yang ada di Kawasan Besuki, Kawasan Ponorogo dan Tuban. Penelitian pemanfaatan lahan gua di Kawasan Jember misalnya menunjukan adanya adanya fungsi dan karakteristik yang berbeda dari masing-masing gua yang berada dalam satu kawasan. Perbedaan jenis dan intensitas temuan digunakan untuk membangun hipotesis tersebut. Di kawasan ini gua memiliki pola pemanfaatan yang berbeda yaitu dengan adanya gua hunian sebagai pusat serta gua-gua lain yang memiliki fungsi yang berbeda sebagai pendukung aktifitas 
penghuni gua yang terletak di wialayah pusat (Nurani, 1995).

Keberadaan Gua Wuru dan himpunan temuannya telah menunjukan hubungan keruangan dengan gua-gua lain yang ada disekitarnya. Gua lain yang dimaksud salahsatunya adalah Gua Tritis Ngloro yang secara morfologis, lingkungan dan kandungan data menunjukan potensi sebagai hunian manusia masa prasejarah. Gua Tritis Ngloro memiliki kedekatan dengan sumber air yaitu Tlogo Ngloro serta memiliki morfologi yang cukup ideal yaitu ruangan yang lebar dengan pencahayaan dan sirkulasi udara yang baik. Selain Gua Tritis Ngloro terdapat pula Gua Watu Glundung, Gua Tlogo Randu, Gua Wura-Wari, Gua Putat $A$ yang berdasarkan hasil survey dinilai memiliki potensi arkeologis sebagai hunian manusia prasejarah (Alifah, 2013 dan Sofian, 2007). Kondisi ini menggiring pemikiran keterkaitan antara lingkungan dan keletakan gua yang ada disekitarnya. Temuan-temuan ekofak di Gua Wuru mampu memberi gambaran tentang kondisi lingkungan yang berbeda dengan kondisi lingkungan saat ini. Temuan tulang binatang yang beberapa di antaranya menunjukan pola hidup berkoloni atau mengelompok, seperti rusa, kerbau, dan sapi menunjukan bahwa lingkungan di sekitar Gua Wuru merupakan wilayah hutan yang cukup luas yang menyediakan tempat untuk habitat binatangbinatang tersebut. Sesuai dengan pandanga Steward, bahwa kondisi lingkungan menuntut manusia untuk menyesuaikan diri atau beradaptasi. Adaptasi yang tercermin dalam budaya manusia di sekitar Gua Wuru adalah subsitensi berburu. Kondisi lingkungan yang menyediakan banyak binatang yang hidup dihabitat tertentu inilah yang menuntun manusia untuk melakukan aktivitas berburu dan pengolahan makanan di sekitar Gua Wuru.
Penggunaan Gua Wuru sebagai aktivitas sementara ini menunjukan bahwa manusia pada masa itu telah memanfaatkan Gua di sekitar Gua Wuru untuk aktivitas yang lebih menetap atau camp site.Seperti yang disampaikan oleh Yuwono, 1995 bahwa masyarakat pemburu dan peramu memiliki kecenderungan hidup nomaden, namun mereka memilih lokasi tertentu untuk dijadikan sebagai came site. Sebagai sebuah lokasi yang dipilih sebagai came site diharuskan memiliki kedekatan dengan sumber air. Di sekitar Gua Wuru terdapat gua-gua lain yang memiliki potensi arkeologi sebagai hunian manusia masa prasejarah.

Berdasarkan persebaran gua-gua hunian yang ada di sekitar Gua Wuru terlihat bahwa gu-gua tersebut berada pada radius kurang dari 2 kilometer dari sumber air. Keberadaan sumber air sebagai pemenuhan kebutuhan hidup mengambil posisi yang utama dalam penentuan pola persebaran hunian tersebut dengan asumsi bahwa sebagai sebuah tempat yang nyaman untuk bermukim, gua yang dipilih harus memiliki sumberdaya untuk pemenuhan kebutuhan dasar yang mudah untuk dijangkau.

\section{KESIMPULAN}

Temuan hasil survey di Gua
Wuru dapat digunakan untuk
mengungkap beberapa aspek kehidupan manusia prasejarah yang ada di sekitarnya. Interpretasi terhadap seluruh data baik data artefak, ekofak maupun lingkungan telah menunjukan bukti-bukti aktivitas yang berlangsung di Gua Wuru dan sekitarnya. Berdasarkan analisis ekofak, artefak, lingkungan dan peta disimpulkan bahwa Gua Wuru merupakan sebuah gua yang memiliki potensi arkeologi sebagai transite site (tempat tinggal 
sementara) yang memiliki hubungan keruangan dan fungsi dengan guagua di sekitarnya. Gua-gua yang berada disekitar Gua Wuru berfungsi sebagai came site (tempat tinggal utama) karena didukung oleh kondisi morfologi gua dan lingkungan yang "nyaman". Keletakan Gua Wuru di lereng bukit serta lembah terbuka yang berada di dua puncak perbukitan dimanfaatkan untuk aktivitas yang berkaitan dengan berburu binatang berupa jenis Cervus dan Bos. Berdasarkan temuan ekofak yang mulai mengalami fosilisasi maka diperkirakan penggunaan gua ini telah dimulai sejak 7.000 yang lalu. Interpretasi ini masih memiliki titik kelemahan mengingat konteks statigrafis dari temuan yang ada sudah tidak diketahui namun demikian kelemahan ini dapat minimalisir denganmelakukan perbandingan temuan yang ada di gua-gua sekitar Gua Wuru. Sejauh ini penelitian gua-gua di sekitar Gua Wuru baru sebatas survey permukaan sehingga perlu dilakukan penelitian berupa ekskavasi di guagua tersebut, terutama Gua Tritis Ngloro da Gua Putat A untuk lebih memahami pola pemanfaatan gua secara meso di sekitar kawasan gunung Sewu bagian barat.Penelitian lebih mendalam diharapkan mampu menjelaskan adanya karakteristik pemanfaatan lahan gua sesuai dengan kondisi lingkungan Gunung Sewu pada masa lalu.

Ucapan terima kasih disampaikan kepada Taufiqurrahman Setiawan yang telah membantu dalam menggambar peta sehingga dengan bantuan gambar tersebut membantu penulis untuk memahami hubungan antara Gua Wuru dan Gua lain, serta lingkungan yang ada disekitarnya. 


\section{DAFTAR PUSTAKA}

Ahimsa-Putra, Heddy Shri. 1995 "Arkeologi Pemukiman: Titik Strategis dan Beberapa Paradigma ". Berkala Arkeologi XV edisi khusus. Yogyakarta: Balai Arkeologi

Alifah, 2013. "Potensi Arkeologi Gua-Gua di Kecamatan Saptosari". Berita Penelitian Arkeologi. Yogyakarta: Balai Arkeologi.

Bintarto, R, 1995. "Keterkaitan Manusia, Ruang dan Kebudayaan". Berkala Arkeologi Edisi Khusus. Yogyakarta: Balai Arkeologi.

Dharma, Bunjamin.1992. Indonesian Shells II. Jakarta: P.T. Sarana Graha

Haryono, Eko. 2001. "Nilai Hidrologis Bukit Karstt". Seminar Nasional Ekobidrolik 28-29 Maret 2001. Yogyakarta: Jurusan Teknik Sipil UGM

Hole, Frank and Robert F. Heria, 1973. An Introduction to Prehistoric Archaeology. New York: Holt Reinhart \&Winston.

Hudayana, Bambang. 2001. "Pendekatan Marxis dalam Antropologi Ekonomi".Laporan Penelitian. Yogyakarta: Fakultas IImu Budaya.

Judge. W.J.1971. "An Interpretive Framework for Understanding site Locations".The Distribution of Prehistoric Population Anggregates. Antropological Reports.

Mundarjoto, 1995. "Kajian Kawasan: Pendekatan Strategis dalam Penelitian Arkeologi Indonesia Dewasa Ini”. Berkala Arkeologi Edisi Khusus. Yogyakarta: Balai Arkeologi.

Nurani, Indah Asikin, 1995. "Pola Pemukiman Gua-gua di Kaki Gunung Watangan: Suatu Hipotesis Pemukiman Gua Kawasan Timur Jawa". Berkala Arkeologi XV edisi khusus. Yogyakarta: Balai Arkeologi

2006. "Pemanfaatan Lahan Gua Di Jawa". Permukiman di Indonesia: Prerspektif Arkeologi. Jakarta: Puslit Arkenas.

Prasodjo, Tjahyono. 2002. "Analisis Artefak Batu Situs Gua Bentar dan Gua Blendrong, Ponjong Gunung Kidul'. Laporan Penelitian. Yogyakartta: FIB UGM.

Said, Chaksana A.H dan Bambang Budi Utomo. 2006. "Pemukiman dalam Perspektif Arkeolog" dalam Pemukiman di Indonesia, Perspektif arkeologi. Jakarta: Pusat Penelitian dan Pengembangan arkeologi Nasional

Simanjuntak, Truman, 1999. "Budaya Awal Holosen di Gunung Sewu". Berkala Arkeologi edisi no.1/Mei. Yogyakarta: Balai Arkeologi

Simanjuntak, 2000. "Hunian Gua dan Ceruk: Trend Baru Pada Akhir Plestosen" dalam. Prasejarah Gunung Sewu.Jakarta: IAAI. 
Siswanto, 2012. "Menuju Konservasi Karstt Dan Situs-Situs Arkeologinya", Dalam Warisan Sumberdaya Arkeologi Dan Pembangunan. Yogyakarta Penerbit Ombak

Sofian, Hari Oktavianus, 2007. "Survei Arkeologi Potensi Gua Di Kecamatan Paliyan Kabupaten Gunung Kidul". Skripsi. Yogyakarta: Fakultas IImu Budaya UGM.

Subroto, Ph. 2005. "Pola-Pola Zonal Situs-Situs Arkeologi". Berkala Arkeologi XV edisi Khusus. Yogyakarta: Balai Arkeologi

Steward, J.H., 1995. Theory of Culture Change. Urbana: University of Illinois Press.

Tim, 2013. "Potensi Arkeologi Gua-Gua di Kawasan Gunung Sewu Bagian Barat. Tahap I (Kecamatan Saptosari). Laporan Penelitian. Yogyakarta: Balai Arkeologi.

Widianto, Harry, 2006. "Peran dan Pentingnya Fosil bagi Ilmu Pengetahuan". Berkala Arkeologi Edisi 1/ Mei. Yogyakarta: Balai arkeologi Yogyakarta

Yuwono, J. Susetyo Edy. 2004. "Arkeologi Karsttik dan Metode Penelusuran Potensi Kawasan: 1Introduksi tentang Model Penerapannya di Gunung Sewu" Makalah disampaikan pada Pendidikan dan Pelatihan Scientific Karst Exploration Tingkat Nasional, Rasamala KPA Sylvalestari dan Lawalata IPB, Bogor, 10-13 April 2004.

Yuwono, Pujo Semedi H. 1995. "Evolusi Teknologi Subsistensi". Humaniora I. Yogyakarta: Fakultas Sastra UGM

http://blog.fitb.itb.ac.id diunduh pada 30 Desember 2014 